\title{
Magnetic Survey for Iron-Oxide-Copper-Gold (IOCG) and Alkali Calcic Alteration Signatures in Gadarwara, M.P, India: Implications on Copper Metallogeny
}

\author{
P.V. Sunder Raju * and K. Satish Kumar
}

Council of Scientific and Industrial Research-National Geophysical Research Institute, Uppal Road, Hyderabad, Telangana 500007, India; satishmarine_777@yahoo.co.in

* Correspondence: pvsraju@ngri.res.in

Received: 24 April 2020; Accepted: 6 July 2020; Published: 29 July 2020

check for updates

\begin{abstract}
A government airborne geophysical survey flown in the late 1970s detected a large Magnetic anomaly at Gadarwara, Madhya Pradesh, in north-central India. Deep drilling indicates that the oval-shaped Magnetic anomaly is caused by underlying Magnetite-bearing banded iron formation belonging to the Mahakoshal Formation of Archean to Early Proterozoic age. The anomaly is hosted in a tectonic rift zone (Narmada-Son Lineament). After drilling alluvium up to $312 \mathrm{~m}$ thick, rocks intersected to depths of $612 \mathrm{~m}$ provided core samples for research. Broadly speaking, the samples contain banded hematite jaspilite (BHJ) and banded Magnetite (BM) iron formation with pervasive carbonate alterations. Three vertical diamond drill holes were drilled along a $1.4 \mathrm{~km}$ long N-S transect across the center of the geophysical anomaly. DDH-1, near the northern edge of the anomaly, went through $309 \mathrm{~m}$ of alluvium before intersecting bedrock and then cored $303 \mathrm{~m}$ of bedrock for a total depth of $612 \mathrm{~m}$. Copper mineralization with appreciable amounts of cobalt, zinc, molybdenum, silver, rare earth elements, uranium and other elements was intersected. The litho-units are highly oxidised and intensely brecciated with hydrothermal overprinting of Na-K metasomatism alteration mineralogy. The second borehole, DDH-2 failed as the core drilling bit stuck in the alluvium and further drilling was abandoned, whereas the third borehole DDH-3 didnot intersect a Magnetite-hematite association and cored only siltstone. Two-dimensional model studies suggest that the signature of high Magnetic anomaly is at a depth of $0.4 \mathrm{~km}$ from the surface, with a width of $3.5 \mathrm{~km}$, dipping at $45^{\circ}$ in a northerly direction. The causative body has a Magnetic susceptibility of 0.0052 C.G.S. units, suggestive of a hematite with quartz veinlets lithology. Based on predictive Magnetic exploration models for Iron-Oxide-Copper-Gold (IOCG), such deposits can be inferred from geological observations combined with petrophysical data and forward modelling of the observed Magnetic signatures. This paper reports a prospective IOCG-like mineralization style hosted in a rift (Narmada-Son) type of tectonic environment.
\end{abstract}

Keywords: Gadarwara; central India; mineralization; IOCG; Narmada-Son-Lineament; Magnetic anomaly

\section{Introduction}

Magnetic surveys are rapid and provide clues from prospect to province. Magnetic anomalies can also provide direct signatures of certain types of ore deposit or mineralization. IOCG provinces extent across the globe and range in geological timescales from Archean to Cenozoic and include the modern examples such as Iron-Oxide Copper Gold (IOCG), the Kiruna type $\mathrm{IO} \pm \mathrm{A}$ (Iron Oxide Apatite) [1,2]: Examples include the Gawler craton [3,4], Olympic Dam, Clonclurry, Tennant Creek in Australia [5-8], Kiruna in Sweden and Carajas, in Brazil [9,10], and the lesser understood Wernecke [11], 
Great Bear Magmatic zone [12] in the Canadian shield [12], Khetri [6,13] and Singhbhum [14] deposits in India. The majority of these key deposits and districts are Paleo- or Mesoproterozoic in age, they have vast extents $<35 \mathrm{~km} \times 1.5 \mathrm{~km}$, occur at depths of 3-10 km in an active Magmatic setting [15].

They can vary in alteration facies (Na-Ca-Fe-K-Mg) and chemical footprints range from $\mathrm{cm}-\mathrm{m}-\mathrm{km}$ scale [16]. The salient features of IOCG include the following [6]: (1) The occurrence of copper $(\mathrm{Cu})$ with or without gold $(\mathrm{Au})$; (2) Hydrothermal vein, breccia or replacement ore styles characteristically in specific structural sites; (3) Abundant Magnetite or hematite; (4) Iron oxides which have low Ti contents compared to those in most igneous rocks and bulk crust, in particular nelsonites and igneous Fe-Ti deposits; (5) Absence of clear spatial association with igneous intrusions.; (6) Strong structural and stratigraphic control; (7) abundant hydrothermal-structural breccia zone. The geological architecture and evolution of India show it to have rocks from Archean to Phanerozoic ages, and suitable geological settings [6] as potential hosts for IOCG/Kiruna-type deposits. However, in India reports on IOCG are documented from the Bhukia IOCG-IOA deposit of Aravalli-Delhi Fold Belt, Rajasthan, western India [14,17], Thanewasna, Western Bastar Craton [18], Singhbhum Craton [14], and Machanur, Eastern Dharwar Craton [19] (Figure 1). The Council of Scientific and Industrial Research- National Geophysical Research Institute (CSIR-NGRI), India carried out an airborne geophysical survey flown in the late 1970s and detected a sizeable Magnetic anomaly at Gadarwara, Madhya Pradesh, in north-central India [20] with only scanty follow-up studies. For the first time, we provide the geophysical signatures using an integrated investigation with new insights on geophysical and geochemical characteristics of these rocks and offer unique constraints on the nature and significance of the IOCG mineralization at Gadarwara, Madhya Pradesh, India.

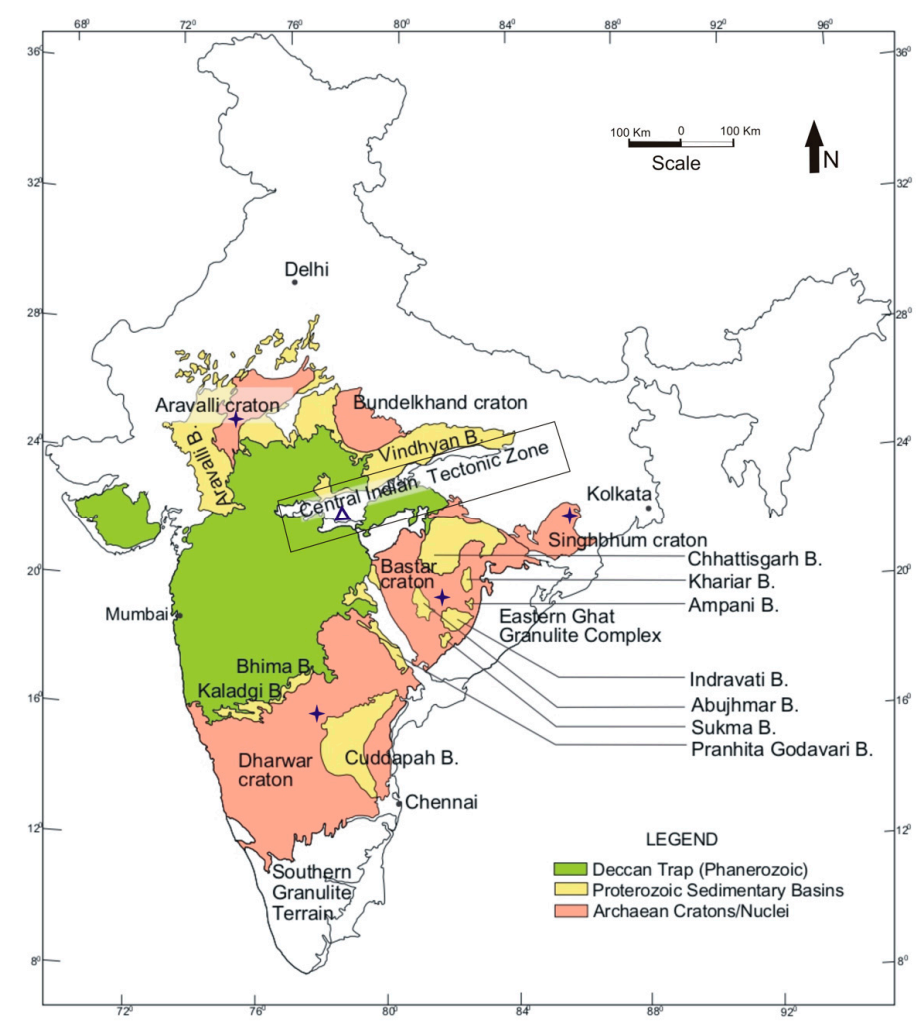

Figure 1. Simplified geological Map of India showing position of five cratonic blocks and sedimentary basins (after Mazumder et al., 2019a [21]) with reported IOCG deposits (blue stars) and study area in (triangle).

\section{Regional Geology}

The Son- Narmada-Tapti fault (NSF) is one of India's most prominent geomorphic features and cuts across the central part of the Indian subcontinent [1]. This east-northeast (ENE) to west-southwest (WSW) trending lineament extending in length of about $\sim 1200 \mathrm{~km}$ from $72.5^{\circ} \mathrm{E}$ to $82.5^{\circ} 5^{\prime \prime} \mathrm{E}$ long 
and $21.5^{\circ} \mathrm{N}$ to $24^{\circ} \mathrm{N}$ latitude (Figure 2a). The NSF structural zone juxtaposes disparate and complex geological and geophysical characteristics and comprises a broad region (up to $30 \mathrm{~km}$ wide) of linear topographic features, contemporary seismicity, and hot springs [22]. The NSF is currently expressed as an alluvium-filled tectonic rift zone with northern and southern bounding faults. More importantly, the Son- Narmada-Tapti fault divides the Bundelkhand Craton to the north from the Dharwar Craton to the south. The Bundelkhand Craton consists of Archean amphibolitic and ultramafic slivers of greenstone belt association within a broader region of poly-metamorphosed sialic and TTG gneisses (ca. 3.5-2.7 Ga), metamorphosed volcano-sedimentary rocks, and syn- to post-tectonic granitoids (ca. 2.5-2.4 Ga), and granitoids that include a significant Paleoproterozoic component.The older rock packages are cut by at least three generations of Mafic dyke swarms, most importantly the ca. $1700 \mathrm{Ma}$ dolerite dykes that are likely related to the development of rift basins of the Bijawar (or Mahakoshal Group) and Gwalior Formations. The overall tectonic trend of the Bundelkhand Craton (Figure $2 b$ ) is E to ENE flanked along its southern and northwestern Margins by the Pre-Vindhyan siliciclastic shelf sequence of the Bijawar Formation. The eastern, western and southern Margins of the BKC are covered by Vindhyan Group rocks (1400 Ma and younger), while the alluvium is covered in the northern border [23]. The stratigraphy of study area is shown in Table 1.

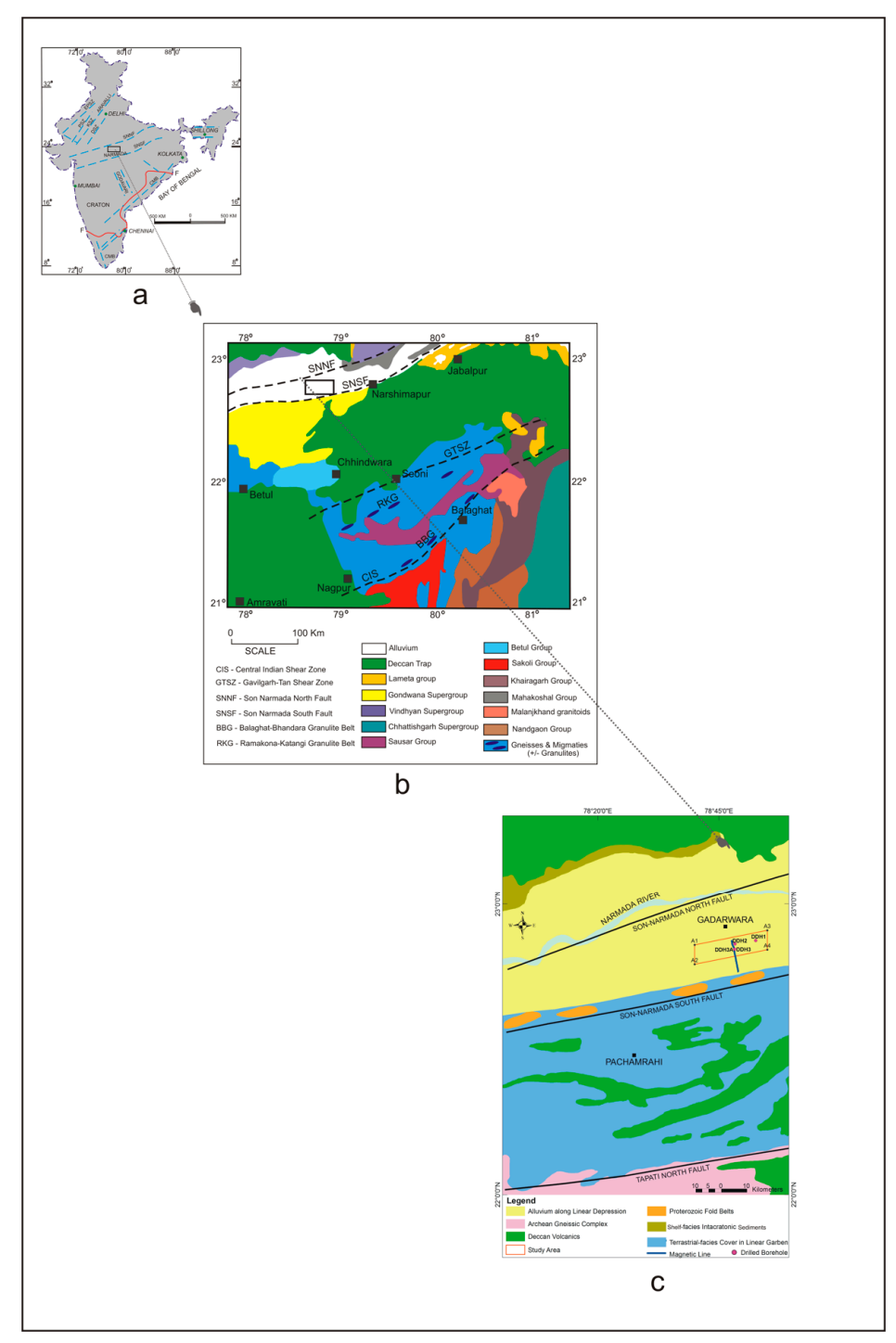

(A)

Figure 2. Cont. 


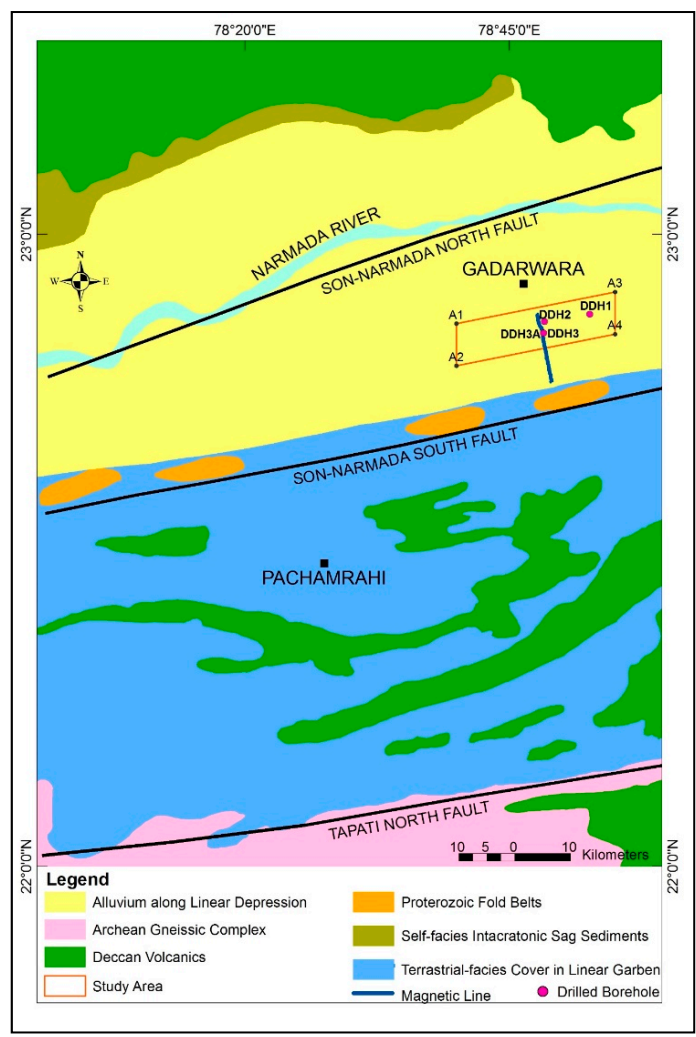

(B)

Figure 2. (A): (a) Simplified Tectonic Map of India; (b) Simplified geological Map of the Central Indian Tectonic Zone in central India, showing all the supracrustal belts and tectonic lineaments (modified after Yedekar et al. 1990 [24], Acharyya and Roy 2000 [25], Chattopadhyay and Khasdeo 2011 [26]; (c) Geological Map of Study area (after Sunder Raju., 2014 [27]. (B) Geological Map of the Study area.

Table 1. The stratigraphic sequence of the Narmada-Son lineament belt.

\begin{tabular}{|c|c|c|}
\hline Age & & Group \\
\hline Recent & & Alluvium (study area) \\
\hline Pleistocene & & Laterite \\
\hline Eocene & & $\begin{array}{c}\text { Trap intrusions, dolerite dykes, } \\
\text { intertrappean beds, Deccan trap dikes, } \\
\text { Deccan trap flows, Bagh beds, Lameta beds } \\
\text { unconformity }\end{array}$ \\
\hline Lower Cretaceous & Gondwana & Upper Gondwana \\
\hline Upper Carboniferous & & Lower Gondwanas \\
\hline Lower Paleozoic & Vindhyan & Upper Vindhyans \\
\hline Upper Precambrian & Super Group & Lower Vindhyans \\
\hline Lower Proterozoic & Bijawar Group & $\begin{array}{c}\text { Limestones, quartzites } \\
\text { unconformity }\end{array}$ \\
\hline Archean & & Granites, gneisses, schists and phyllites \\
\hline
\end{tabular}

The generalise stratigraphic succession of the region (modified after Geological Survey of India publication: Mallet 1869 [28]; GSI, 1976 [29]).

The Mahakoshal Supergroup (Figure 2b) has a linear, east-north-easterly-trending zone between the two cratonic regions (Dharwar, Bundelkhand) and mostly exposed within the bounding faults of the Narmada Son Lineament [30]. The Bundelkhand craton consist of metavolcanic and metasedimentary rock sequences with significant basic/ultrabasic intrusions formed in a rift environment [30]. The older parts of the Mahakoshal Supergroup are siliciclastic and variably referred to as the Bijawar group (ca 2600-2400 Ma) [31] which at their type section in the Son Valley, lacks the deformation and associated intrusions of the Mahakoshal in the Narmada valley. The Mahakoshal Supergroup includes the Sakoli and Nandgaon bimodal volcanics with Dongargarh and Malanjkhand K-granite island-arc type 
intrusions from a Paleoproterozoic period (2.2-2.3 Ga) in the Bhandara craton. The Mahakoshal Group exposed in the Son valley was intruded by Alkali syenite and lamprophyre at $1796 \mathrm{Ma}$ to $1610 \mathrm{Ma}$ [32]. The Mahakoshal was deformed by folding and faulting resulting from Meso- to Neoproterozoic convergence [30] and is therefore locally and otherwise known as the Mahakoshal Deformed Zone. The Vindhyan Basin (Figure $2 b$ ) rocks unconformably overlap upon older Mahakoshal and Bijawar Supergroups and Bundelkhand cratonic rocks. The Vindhyan Group consist of quartzites of 5-6 km thick pile associated with metasedimentary rocks that are divisible into a Lower Group (Semri Series) of $\sim 1.7 \mathrm{Ga}$ [33] and Upper Group (Kaimur, Bhander and Rewa Series) that are 1.1 to 0.7 Ga. Pyroclastic units and felsites and sedimentological changes indicate changes in basin architecture, likely due to fault reactivations [34]. Vindhyan Group rocks are flat-lying and have not been intruded by granitoids. The northern limit of the Central Indian Tectonic Zone (CITZ) is defined by the ENE-WSW trending Son Narmada North Fault (SNNF) and is traceable from Markundi in Uttar Pradesh in the east to Hosangabad in Madhya Pradesh in the west [25]. Geologically, the lineament bounds are represented by two faults, and the Mahakoshal rocks are dominant in between these two faults, Son Narmada South Fault (SNSF) and Son Narmada North Fault (SNNF). (Figure 2c) [35] Further east, the rift faults and associated folds crop out with their subsidiary structures. Locally along the rift in the east, there are gold and base metal deposits of various types which are economically viable [30]. The BIFs found are classified as of Algoma type [30].

\section{Methodology}

\subsection{Magnetic Survey}

A ground Magnetic traverse of 15-line $\mathrm{km}$ was carried out in the study area by a private party. The approximate bearing of the traverse was 170-350'. The survey utilized two GEM Systems GSM-19W Magnetometers, equipped with in-built GPS, and a Geometrics G856 base station Magnetometer, recording the diurnal Magnetic variation at $20 \mathrm{~s}$. intervals. The study area is demarcated in Figure 3 with the Magnetic traverse and drill hole locations.

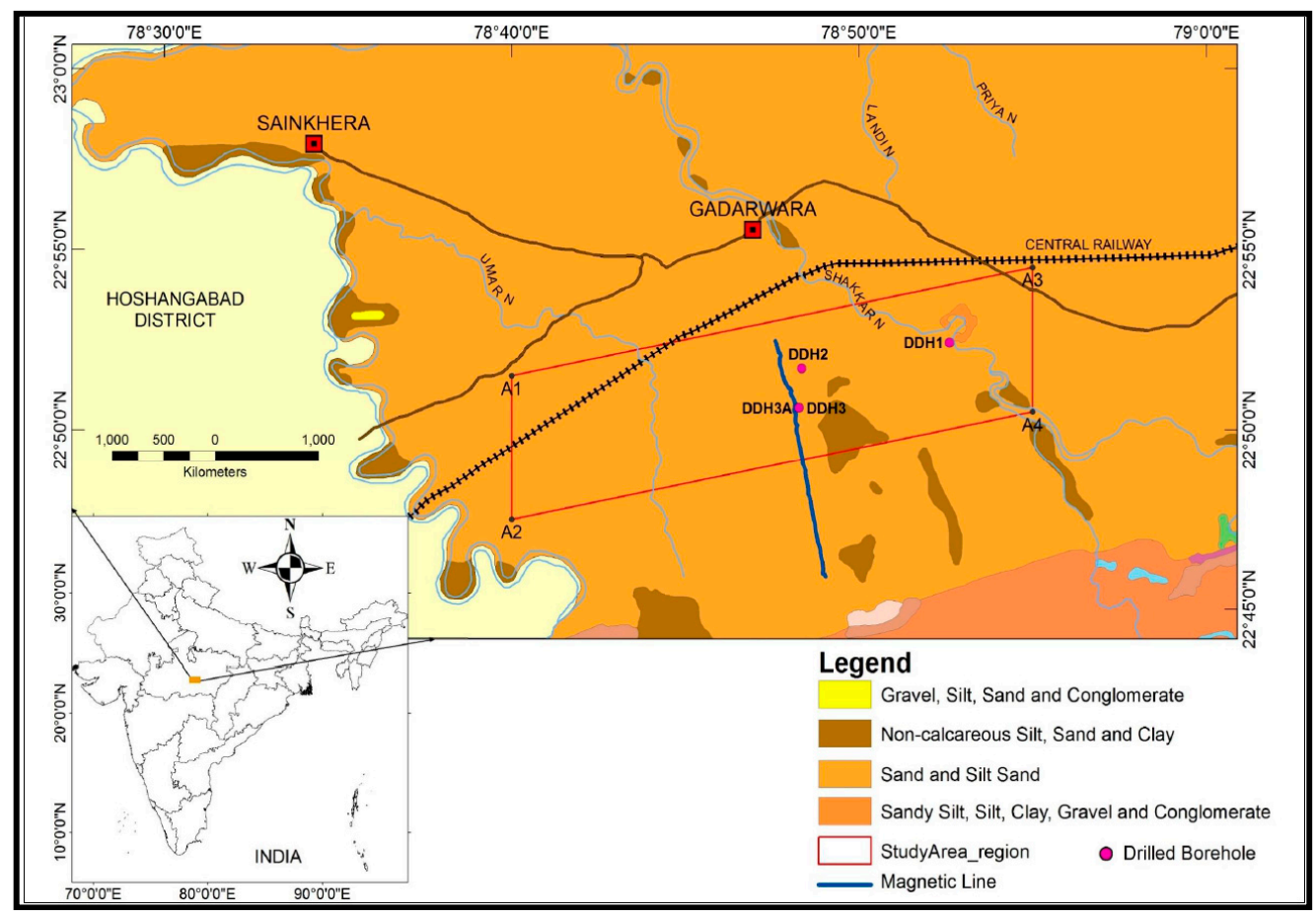

Figure 3. Study area boundaries. 


\subsection{The Gadarwara Magnetic Anomaly}

In 1979, the CSIR-NGRI (-National Geophysical Research Institute, Hyderabad, India) carried out regional aeromagnetic surveys in three blocks along the Narmada Son Lineament for the Geological Survey of India. [36] The Magnetic data collected at a nominal line spacing of $2000 \mathrm{~m}$ at an altitude of $1000 \mathrm{~m}$ ( 3200 feet). This area is mostly covered by thick alluvium and outcrops are sparse with a few exposures of the Mahakoshal Supergroup (Figure $2 b$ ). The aeromagnetic survey picked up a glaring anomaly in the central block located towards the south of Gadarwara town $\left(22.552^{\circ} \mathrm{N}, 78.472^{\circ} \mathrm{E}\right)[31,37]$. The magnitude of the anomaly is about a $600 \mathrm{nT}$, above background values and covers an area of approximately $40 \mathrm{~km}^{2}$. This Magnetic anomaly is widespread andtrends to the east-northeast, and is about $1800 \mathrm{~m}$ wide and $20 \mathrm{~km}$ long. A subsequent ground Magnetic survey better constrained the anomaly to about $1200 \mathrm{nT}$ amplitude [31]. The concealed anomaly is caused by Magnetite bearing "banded Iron Formations" or BIFs. BIFs assemblages are commonly associated with IOCG deposits around the globe [6]. The dominant meta-sedimentary rocks consist of cherty BIF (CBIF) with ribbon-like jasperoids, alternating bands of crypto-crystalline to microcrystalline chert and anhedral hematite with little or no clastic admixture. The thickness of hematite layers varies (1-2 $\mathrm{mm})$ and hosts sericite and chlorite-ripidolite commonly. The dominance of hematite consists of specularite with replacement of silicates and Magnetite. The common gangue mineral phases include quartz, $\mathrm{Ca}(\mathrm{Mg}-\mathrm{Fe})$ carbonates, chlorite, sericite, and apatite. Hematite rocks contain higher sulphidic mineral contents than the Magnetite rocks. REE and U enrichments occur as discrete mineral phases. Accessory zircon and apatite occur as acicular clusters. Magnetite is prominent in all the samples, and in association with hematite. Magnetite grain shapes vary from rounded, sub-rounded, euhedral, amoeboid and mesh-like with Magnetite ex-solution appear like lamellae. Magnetite-dominated assemblages contain apatite as clusters and acicular needles. Sulphides are minor with pyrite $>>$ chalcopyrite. Varying morphologies of zircon, monazite, and xenotime are observed in SEM studies. They are typically of $\sim 25-50 \mu \mathrm{m}$ in size, but difficult to further quantify because of small size and altered character.

The Main sulphides mineral assemblage consists of chalcopyrite and pyrite. In particular pyrite, are round to sub-round grains and occur in interstitial spaces within fine-grained Magnetite. The sulphidic BIFs contain calcite, siderite or ferroan dolomite. Minor hercynitic spinels also occur. The essential Fe-bearing minerals in carbonate are siderite and ankerite, with lesser ferroan dolomite, calcite and Magnesium siderite.

\section{Results}

\subsection{Drilling Results}

In 2007, Adi Gold Mining Pty. Ltd. (New Delhi, India) initiated an exploration program to drill a $1.4 \mathrm{~km}$ fence of three vertical diamond drill holes from north to south across the center of the geophysical anomaly. DDH-1 was drilled (Figure 4 and Table 1) from near the northern edge of the anomaly, went through $309 \mathrm{~m}$ of alluvium coring $303 \mathrm{~m}$ of bedrock for a total depth of $612 \mathrm{~m}$. The litho-units encountered in the drill core (Figure 4 ) include felsic tuff, metasedimentary rocks dominated by banded chert, and various BIF facies, such as cherty BIF, hematite BIF, Magnetite BIF and carbonate BIF. The samples contained carbonate either as a component of the rock Matrix, within coarse-grained, quartz-rich segregations parallel to the metamorphic foliation, or in cross-cutting veins. Rock samples that were taken from drill cores had coatings of travertine, iron/jaspilite and iron oxides. The sample locations and lithology are listed in Table 2. Furthermore, the XRD results suggest and confirm the presence of sheet silicates (i.e., kaolinite, montmorillonite, dickite, mica, chlorite), iron oxides, quartz, and carbonate, etc. The DDH 1 core was strongly weathered to alteration products with hematite and goethite, and the iron oxides, Making explicit recognition of banded hematized Magnetite, red jasper and white chert beds, difficult. The beds are tightly folded, and veinlets of quartz are not uncommon with pseudomorphs and cubic cavities left by oxidized pyrite. DDH-2 advanced through $288.8 \mathrm{~m}$ of alluvium before being abandoned. DDH 3, located near the southern edge of the anomaly, 
went to $307.0 \mathrm{~m}$ depth before being lost in alluvium. DDH-3A (drilled from a location adjacent to DDH-3) intersected bedrock at $312 \mathrm{~m}$ and cored until a depth of $430.8 \mathrm{~m}$, retrieving $118.4 \mathrm{~m}$ of the core. Although boreholes had been drilled in this region during past exploration efforts looking for coal [38,39], these are presumed to be the first deep drill holes to intersect Precambrian bedrock in the Narmada Son lineament.

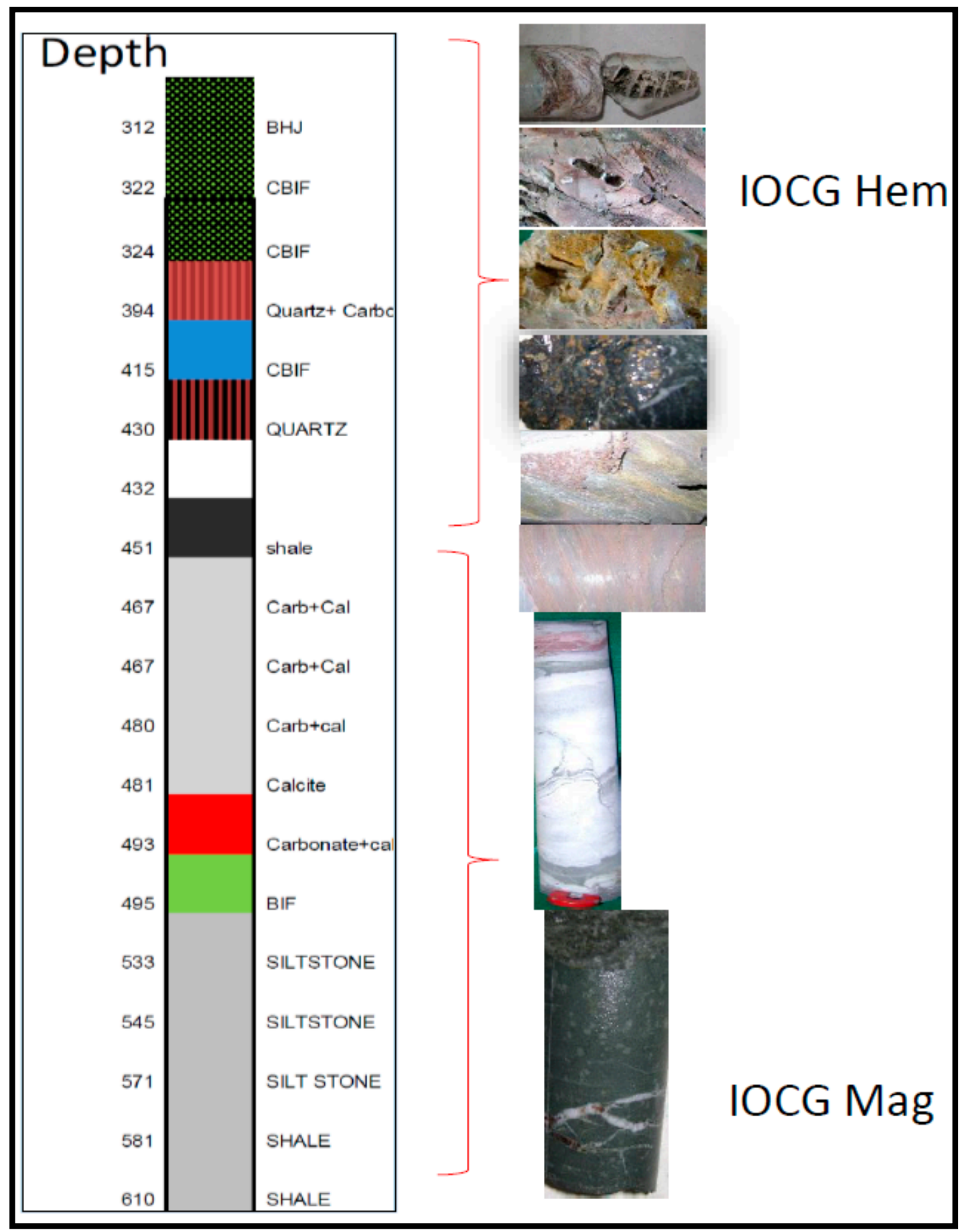

Figure 4. Core Log, Lithounits and core section of borehole DDH-1. 
Table 2. Core section lithology of DDH-1.

\begin{tabular}{|c|c|c|}
\hline $\begin{array}{l}\text { Depth } \\
\text { (in mts) }\end{array}$ & Litho-Unit & Description \\
\hline 312 & $\mathrm{BHJ}$ & $\begin{array}{c}\text { Dark brown to reddish brown in colour, intensely weathered and fractured, } \\
\text { banded-hematite-jasper }(\mathrm{BHJ}) \text {, non-magnetic, specular hematite showing metallic } \\
\text { lustre thin }<1 \mathrm{~mm} \text {, fine grained jasper and hematite, soft yellow limonitic } \\
\text { staining is noted at the fractured planes. The sulphides are pyrite, chalcopyrite } \\
\text { and iron hydroxide like hematite. }\end{array}$ \\
\hline 322 & Cherty IF & $\begin{array}{l}\text { Weathered cherty iron bearing formation, the fine grained chert is hard and shiny } \\
\text { lustre with sulphides and mostly pyrite, chalcopyrite and weathered staining on } \\
\text { surface could be due leaching of iron oxides }\end{array}$ \\
\hline 324 & Cherty IF & $\begin{array}{l}\text { Weathered cherty iron bearing formation, the fine grained chert is hard and shiny } \\
\text { lustre with sulphides and mostly pyrite, chalcopyrite and weathered staining on } \\
\text { core surface. }\end{array}$ \\
\hline 394 & Quartz + Carbonate & $\begin{array}{l}\text { Dark brown to reddish brown in colour, intensely weathered and fractured, } \\
\text { banded-hematite-jasper (BHJ), non-magnetic, specular hematite showing metallic } \\
\text { lustre thin }<1 \mathrm{~mm} \text {, fine grained. Due to intense weathering process the argillite's } \\
\text { are altered to clay and to limonitic ( yellow powdery nature) at carbonate show } \\
\text { reactive nature with intense effervescence }\end{array}$ \\
\hline 415 & CIF & $\begin{array}{l}\text { Weathered cherty iron bearing formation, the fine grained chert is hard and shiny } \\
\text { lustre with sulphides and mostly pyrite, chalcopyrite and weathered staining on } \\
\text { surface could be due leaching of iron oxides. }\end{array}$ \\
\hline 430 & Quartz & Fine grained quartz vein sample with saccharoiadal texture. \\
\hline 450 & Shale & $\begin{array}{l}\text { Grey to dark grey in colour, very fine grained, carbonate rock with calcite } \\
\text { occurring as grey bands of sulphidic minerals and often as relict textures. } \\
\text { Both fine bands of purple coloured minerals varying from white to purple green. }\end{array}$ \\
\hline 467 & Carbonate + Calcite & $\begin{array}{l}\text { Carbonate show reactive nature with intense effervescence with typical calcite } \\
\text { texture perfect cleavage and conchoidal with brittle around with gentle hardness. }\end{array}$ \\
\hline 480 & Carbonate + Calcite & $\begin{array}{l}\text { Carbonate show reactive nature with intense effervescence with typical calcite } \\
\text { texture perfect cleavage and conchoidal with brittle around with gentle hardness. }\end{array}$ \\
\hline 481 & Calcite & $\begin{array}{l}\text { Calcite typical texture with perfect cleavage and conchoidal with brittle around } \\
\text { with gentle hardness. }\end{array}$ \\
\hline 493 & Carbonate + Calcite & $\begin{array}{l}\text { Carbonate show reactive nature with intense effervescence with typical calcite } \\
\text { texture perfect cleavage and conchoidal with brittle around with gentle hardness. }\end{array}$ \\
\hline 495 & Iron Formation & $\begin{array}{l}\text { Dark brown to reddish brown in colour, intensely weathered and fractured, } \\
\text { banded-hematite-jasper(BHJ), non-magnetic, specular hematite showing metallic } \\
\text { lustre thin }<1 \mathrm{~mm} \text {, fine grained jasper and hematite, soft yellow limonitic } \\
\text { staining is noted at the fractured planes. The sulphides are pyrite, chalcopyrite } \\
\text { and iron hydroxide like hematite. }\end{array}$ \\
\hline 533 & Siltstone & $\begin{array}{l}\text { Grey to dark grey in colour, very fine grained, carbonate rock with calcite } \\
\text { occurring as bands with grey mineral and often as relict texture, fine bands of } \\
\text { purple coloured mineral (carbonate-as it reacts with } \mathrm{HCl} \text { ), the colour of } \\
\text { carbonates vary from white to purple and green; fractured. Magnetite } \\
\text { (very fine-grained) crystals as fine zones, Pyrite, Chalcopyrite. }\end{array}$ \\
\hline 545 & Siltstone & $\begin{array}{c}\text { Grey to dark grey in colour, very fine grained, carbonate rock hard and fissile. } \\
\text { The colour of carbonates vary from white to purple and green; } \\
\text { fractured. Magnetite (very fine-grained) crystals as fine zones, Pyrite, } \\
\text { Chalcopyrite. }\end{array}$ \\
\hline 571 & Siltstone & $\begin{array}{l}\text { Grey to dark grey in colour, very fine grained, carbonate rock with calcite } \\
\text { occurring as bands with grey mineral and often as relict texture, fine bands of } \\
\text { purple coloured mineral (carbonate-as it reacts with } \mathrm{HCl} \text { ), the colour of } \\
\text { carbonates vary from white to purple and green; fractured. Magnetite } \\
\text { (very fine-grained) crystals as fine zones, Pyrite, Chalcopyrite. }\end{array}$ \\
\hline 581 & Siltstone & $\begin{array}{l}\text { Grey to dark grey in colour, very fine grained, carbonate rock with calcite } \\
\text { fractured. Magnetite (very fine-grained) crystals as fine zones, Pyrite, } \\
\text { Chalcopyrite and other sulphides. }\end{array}$ \\
\hline 610 & Shale & $\begin{array}{l}\text { Dark grey to black in colour, hard, very fine grained shale with inter-layers of } \\
\text { carbonate; well foliated, fine grains sulphides (pyrite) randomly oriented. }\end{array}$ \\
\hline 610 & Shale & $\begin{array}{l}\text { Dark grey to black in colour, hard, very fine grained shale with inter-layers of } \\
\text { carbonate; well foliated, fine grains sulphides (pyrite) randomly oriented. }\end{array}$ \\
\hline
\end{tabular}


The lithologies encountered in DDH3 consist of banded chert and fine-grained felsic tuff. Some of the beds are thinly laminated, and others are folded in convoluted patterns. Most notably, the drilling intersected an approximately $50 \mathrm{~m}$ thick Magnetite-bearing BIF assemblage. The samples contain banded hematite jaspelite (BHJ) and banded Magnetite (BM) iron formation. Locally, both foliaform and cross-cutting quartz veinlets, with and without traces of fine-grained pyrite are present. All samples have pervasive carbonate alteration. The BIF assemblage likely belongs to the Mahakoshal Supergroup of Archean to early Proterozoic age [30]. This Magnetic anomaly could be explained by the Magnetics method response from underlying Magnetite bearing "banded iron formation" or BIF with around $80 \%$ ferruginous chert-bearing Magnetite (BM), banded hematite jaspilite (BHJ) oxidized iron formations.

\subsection{Magnetic Anomaly Modelling}

The Magnetic anomalies interpretation is normally carried by Matching observed and calculated values of the anomalous Magnetic field. Talwani and Heirtzler (1964) were first to examine a nonmagnetic space containing a uniformly Magnetized two-dimensional structure approximated by a polygonal prism and to suggest a numerical and computational technique of the forward modeling [40].

The modelling is based on the measurements sampled at $200 \mathrm{~m}$ spacing for a $15 \mathrm{~km}$ long profile with traverse bearing of $170-350^{\circ}$ (Figures 5 and 6). The observed ground TMI anomaly is bipolar in nature with an amplitude of $\sim 1200 \mathrm{nT}$ (Figure 6). The basement depth is estimated and calculated using a 1D log normalized radially averaged power spectrum [41,42] (Figure 7a,b). The straight line part of the spectrum at low wave number is considered for depth estimation, $300 \mathrm{~m}$ is attributed to the core litho-log of DDH-1 borehole i.e., top alluvium, outer hematite, inner hematite, alteration of sodic/potassic rocks, hematite breccia, hematite breccia with quartz veinlets and at depth a Massive Magnetite. To understand the signatures of the Magnetic anomalies, initially a synthetic modeling is carried out. (Figure 8) As, the present study area is located in the south of Gadarwara, m.P, Central India bounded by geographic longitudes $78.7931^{\circ}$ to $78.8173^{\circ}$ and latitudes $22.7651^{\circ}$ to $22.8743^{\circ}$. To estimate the geomagnetic components such as Total Magnetic field, Inclination and Declination, we adopted International Geomagnetic Reference Field (IGRF) model-2005 which is closest to surveyed year 2006. As per the IGRF-2005 model, the Total Magnetic Intensity field, geomagnetic inclination and declination of the study area are $44,900 \mathrm{nT}, 33^{\circ}$ and $-0.43^{\circ}$ respectively using Geosoft, 2006 version. The main objective of the synthetic model is to understand the shape of the Magnetic anomaly at this location with respect to observed field Magnetic anomaly. The shape of synthetic Magnetic anomaly will provide the origin of the Magnetic sources at the time of formation. In general, shape of the geomagnetic anomaly varies from equator to pole with a high negative anomaly peak at equator, bi-polar anomaly at $45^{\circ}$ latitude and high positive anomaly peak at poles from south to north [43]. The nature of Magnetic anomaly at this geomagnetic latitude is also dependent to width, depth, depth extent, susceptibility of the Magnetic source, however these parameters influence the width and amplitude of the anomaly only. Hence synthetic anomaly is generated with the known constraints such as Magnetic total field, inclination and declination (IGRF, 2005 model), depth (from DDH 1 borehole data), width [31], dip [31] of the Magnetic sources. In the present case, we observed similarities both in synthetic and observed Magnetic i.e., high positive to low negative from south to north. Hence, remanence Magnetisation might be not present in the causative sources. The shape and width of the anomaly suggests a basement source up to $3.5 \mathrm{~km}$ in width and Rule of thumb depth estimations and examination of the amplitude fall-off rates suggest a depth to Magnetic source of approximately $396 \mathrm{~m}$ depth. 


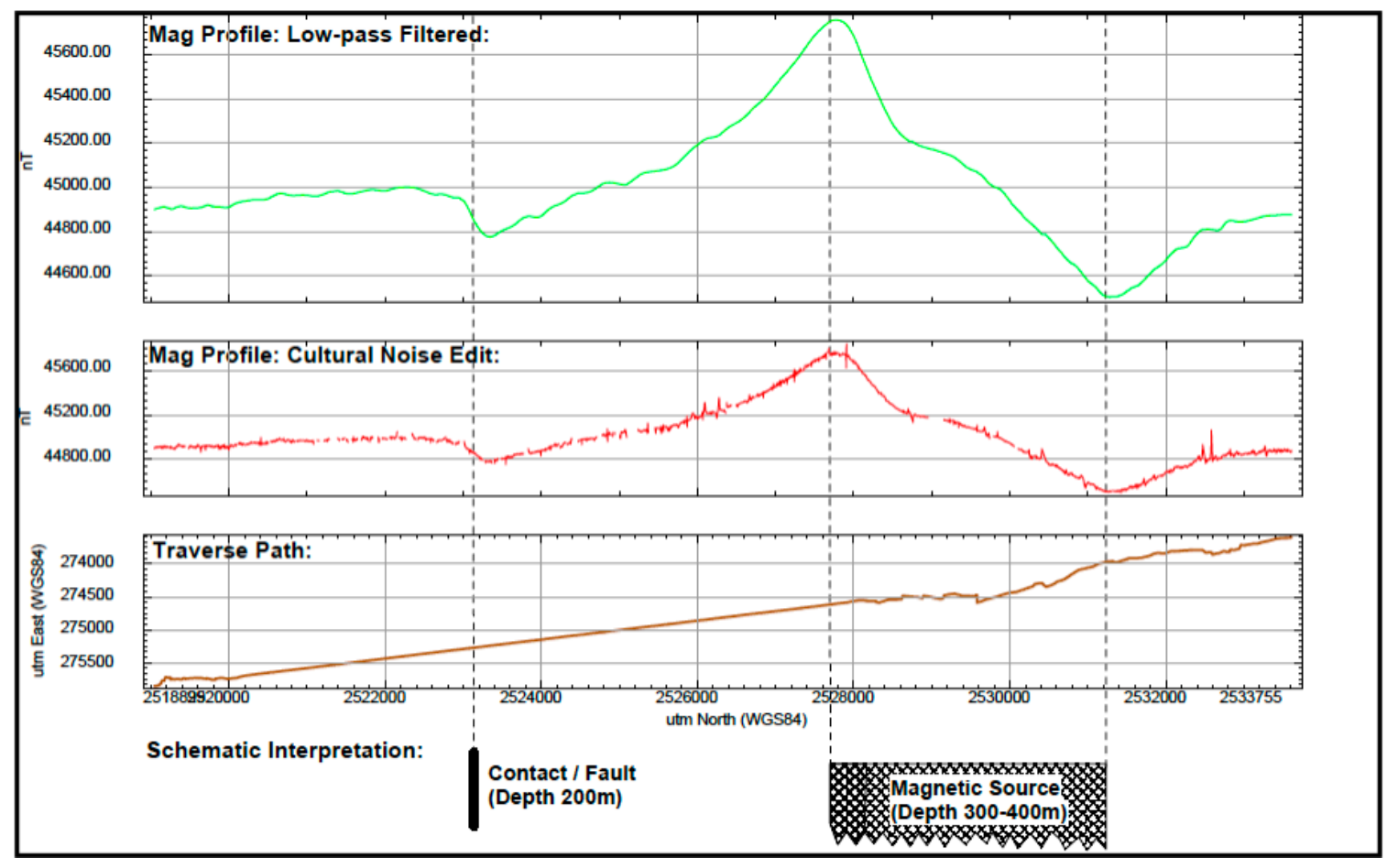

Figure 5. The Magnetic profile along traverse path, Magnetic data and low pass filter.

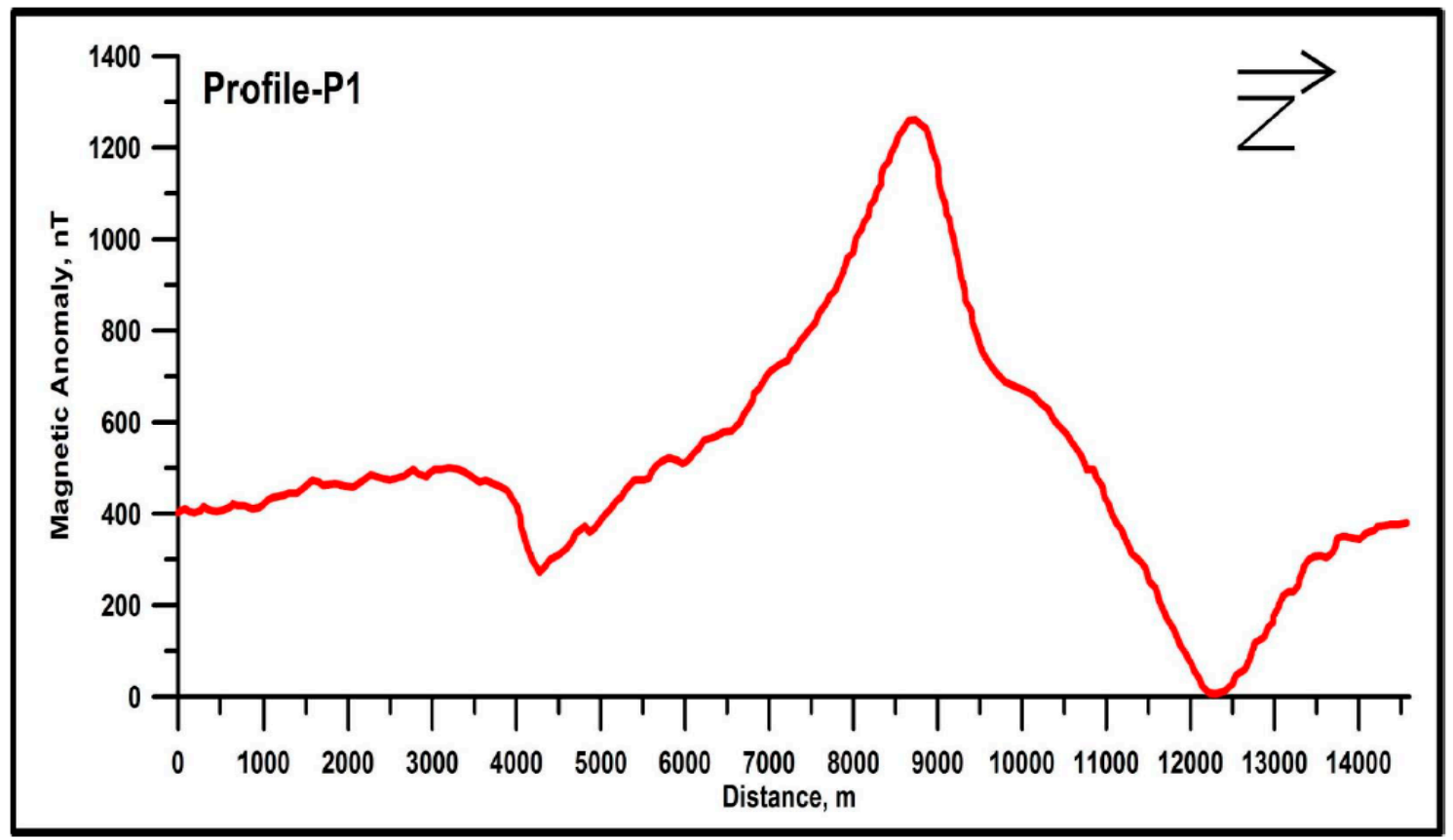

Figure 6. Observed total intensity Magnetic anomaly along profile P1. 

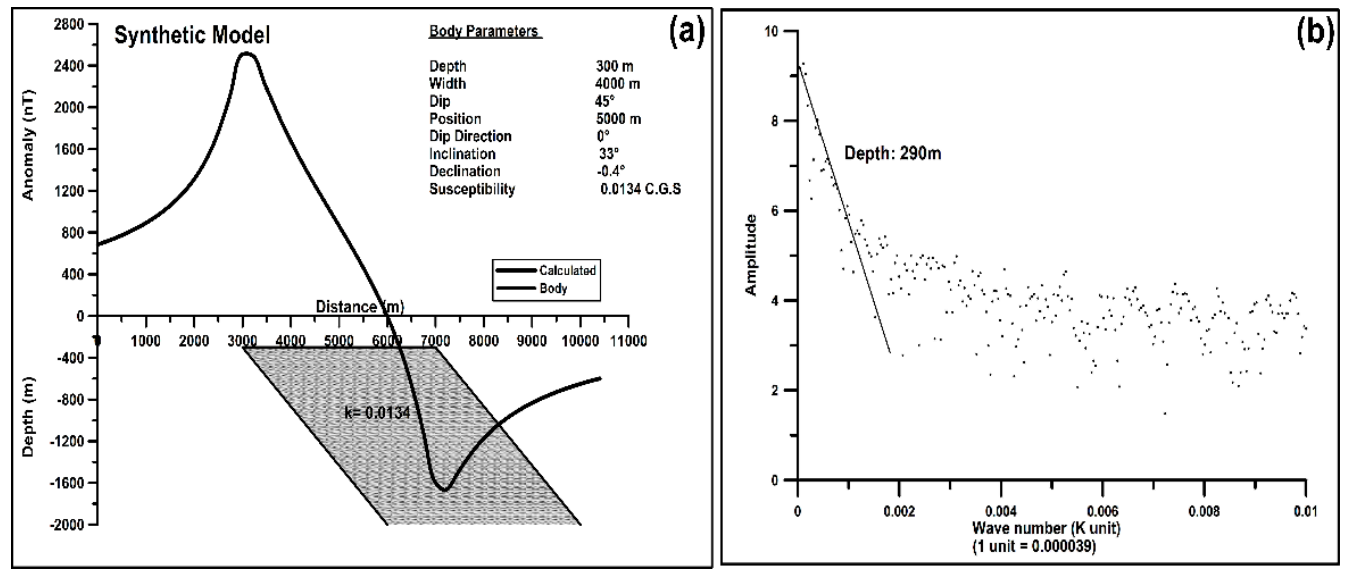

Figure 7. (a) synthetic Magnetic anomaly at geomagnetic latitude and (b) power spectrum Map showing the depth.

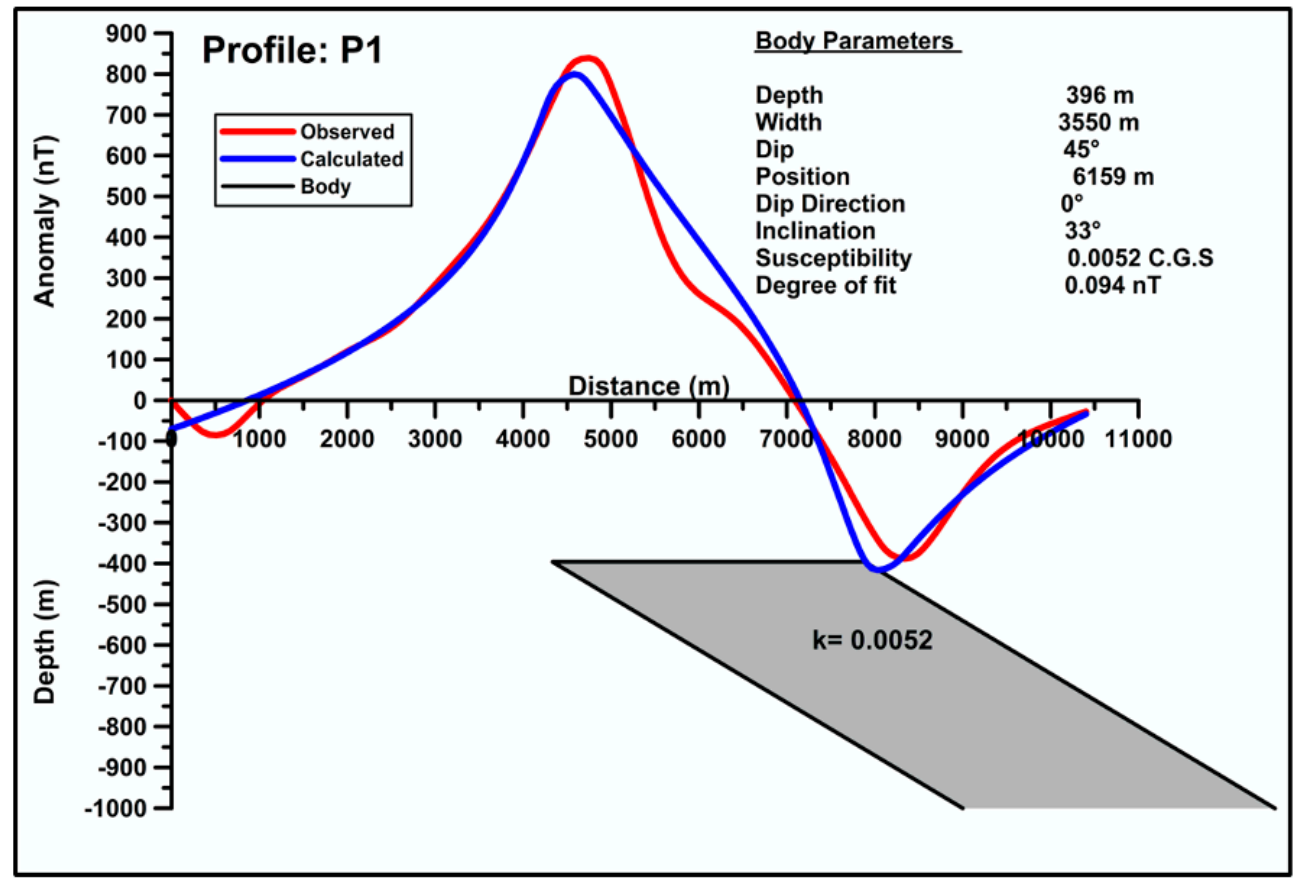

Figure 8. Interpreted 2D depth model for Magnetic anomaly.

The two dimensional model studies were carried using MaGMOD, Ltd., Toronto, Canada [31,44]. The geomagnetic Inclination and declination $\left(33^{\circ}\right.$ and $\left.-0.4^{\circ}\right)$, depth and width $(300 \mathrm{~m}$ and $2000 \mathrm{~m})$ of the causative source, dip $\left(45^{\circ}\right)$, Magnetization $(600 \mathrm{nT})$ and strike $(\mathrm{E}-\mathrm{W})$ direction were used as initial inputs. A bipolar anomaly between 4000 and 14,500 $\mathrm{m}$ is considered for model studies from the profile P1 (Figure 8). The calculated Magnetic anomaly from the interpreted depth model corroborated with the observed anomaly with an R.M.S. error of $0.094 \mathrm{nT}$ (Figure 8). The model studies suggest that the signature of high Magnetic anomaly is obtained from the surface to a depth of $400 \mathrm{~m}$, with the mineralized body width of $3500 \mathrm{~m}$ at a dip angle of $45^{\circ}$ towards north direction. The magnetic susceptibility 0.0052 C.G.S. units correspond to hematite with quartz veinlets lithology.

There is a slight possibility that an additional Magnetic source is located on the southern edge of the broader Magnetic source Manifested by a bipolar anomaly super-position on the Magnetic high coincident with the southern edge. An additional anomaly in the southern portion of the traverse is indicative of a contact or faulting. In general, the magnetic signatures of IOCG systems reflect superposed or juxtaposed Magnetic anomalies inferring a deeper source for the Magnetic anomaly. 
The possible reason could be that the hematite rich zone has been heated $>600{ }^{\circ} \mathrm{C}$ by regional or contact metamorphism and therefore might have acquired sufficient remanence to produce Magnetic anomalies. Hence, the observed Magnetic anomaly is due to the presence of hematite or Magnetite, weathered and oxidised/brecciated iron rich layers at $396 \mathrm{~m}$ depth.

\section{Discussion}

The drill holes DDH 1 and DDH 3 are the first deep drill holes to intersect Precambrian bedrock in the Narmada Son lineament. Unusual geological litho-units cause the geophysical anomaly at depths probably due to underlying Magnetite bearing "banded iron formation" or BIF of around $80 \%$ ferruginous chert-bearing Magnetite (BM), banded hematite jaspelite (BHJ) oxidised iron formations. The basinal fluids preserved in evaporate-bearing sedimentary successions are the important and significant contribution to the fluid budget of hematite-rich IOCG systems. The mineral footprints in the core samples investigated from Gadarwara suggest that samples have undergone hydrothermal, and oxidation alterations of primary mineralisation [45]. The hydrothermal footprint is expressed by intense silicification related to pervasive quartz veinlets. These hydrothermal alteration systems $[2,46,47]$ are typically expressed by silicate and oxide alteration minerals and can be characterized by three zones including: (1) An upper hematite- and/or Magnetite-rich zone, 1-3 km in horizontal diameter, associated with copper and iron sulphides (e.g., chalcopyrite, bornite and pyrite) together with sericite, chlorite and carbonate alteration. In the Olympic Dam copper-gold province it is evident that higher grade copper-gold and/or uranium/rare earth element mineralisation occurs within the upper, hematitic zones [48]. (2) A mid-depth zone rich in Magnetite with biotite or potassium feldspar \pm minor pyrite, showing petrological similarities to core samples investigated typically of a few hundred meters to $\sim 1-3 \mathrm{~km}$ in lateral dimensions. (3) A lower zone with sodic-calcic alteration rich in albite, actinolite \pm clinopyroxene (e.g., diopside), with minor Magnetite, potentially extending laterally up to 5-10 km in Major IOGC provinces such as the Olympic copper-gold province and Cloncurry IOCG district. The major four essential components in IOCG ore systems of Olympic Dam type are (a) the crustal architecture i.e., reactivated orogenic architecture occurring at craton Margin settings, (b) The energy sources to ascent the hydrothermal fluids i.e., High temperature associated with A and I types felsic and coeval Mafic-ultramafic Magmatism. The two stage of mineralization from deep source high temperature brine of Magmatic-hydrothermal and/or basinal origins and shallow sourced lower temperature fluids of meteoric origin, (c) early high temperature iron oxides and (d) late Cu-Au, $\mathrm{Cu}$ from Mainly Mafic sources and U could be from felsic sources and large scale potassic alteration features. The extensive alteration zones of Magnetite, K-Feldspar, actinolite, pyrite, apatite, carbonate, quartz and chalcopyrite produce the Magnetic anomalies [7]. The similarities of oxidised alteration zones May be present above or lateral to Magnetite alteration with high grades of $\mathrm{Cu}-\mathrm{Au}$ mineralisation predicted within hematitic alteration near the transition to Magnetite. Whereas, in Cloncurry $\mathrm{Cu}-\mathrm{Au}$ mineralization overprinting the banded iron formation in similarity to Gadarwara type.

On a cratonic scale in all the IOCG districts the lithounits include felsic intrusions, Mafic dykes, Mafic intrusions, felsic volcanic, BIFs, clastic sediments and carbonate meta evaporates. The Gadarwara is located at the craton Margin hosting meta-sediments especially BIFs with high Magnetite contents with cross cutting dykes, especially associated with shales. The association of copper-gold mineralization with hematitic alteration and hydrothermal Magnetite with associated $\mathrm{Cu}-\mathrm{Au}$ transported by late oxidizing brine solutions that had reacted with meta-sedimentary rocks such as BIFs. The shales could have supplied required sulphur for the sulphide enrichments especially copper sulphides such as chalcopyrite. The geological exploration indicators of REE-bearing meta sedimentary hosts include intraplate continental environments rifting and/faulting, alteration halos, and indicator minerals.

The key styles of copper-gold mineralisation in the Cloncurry district, to the east of Mount Isa is associated with Magnetite and potassium feldspar alteration (e.g., Ernest Henry deposit) whereas another style occurs with pyrrhotite and Magnetite (e.g., Eloise deposit. Both the Ernest Henry and 
Eloise deposits are closely associated with intense Magnetite alteration. In several, Australian deposits Pressure-Temperature modelling shows that the contact zones between Magnetite- and hematite-rich alteration is highly favourable for the formation of higher grade copper-gold mineralisation [5] similar to Gadarwara (Figures 9 and 10). Such redox gradients also appear to be important in the high grade gold-copper-bismuth deposits of the Tennant Creek district, where both Magnetite- and hematite-rich deposits are present in association with chlorite \pm sericite alteration [6-9]. Therefore, the most attractive copper-gold exploration targets identified in Olympic Dam, Tennant creek [4,7], are those relatively small bodies (e.g., <15 km width) where exceptionally dense and Magnetic Material (magnetite \pm pyrrhotite) is laterally or vertically in contact with exceptionally dense bodies of low Magnetic susceptibility (e.g., hematite \pm pyrite \pm copper sulphides). AtOlympic Dam, the zonation is vertically from Magnetite dominated at depth to hematite on surface i.e., upper levels. This pattern could have been altered by Major tectonic activity in the form of tilting or by faulting. It leads to debate on the Magnetic signatures of IOCG deposits which May reflect superposed or juxtaposed Magnetic anomalies [8,49]. At Gadarwara the litho-units like iron rich laminated mudstone-siltstone at depth probably formed as a submarine sedimentary facies. The retrogression and or hydrothermal alteration at upper greenschist/lower amphibolite facies led to Magnetite replacement of protolithic hematite. At lower temperature $<150^{\circ} \mathrm{C}$ veins of hematite develop chalcedony of quartz [1,2]. In Table 3, the comparison of IOCG deposits like Olympic Dam, Cloncurry, Kiruna, Phalborwa and Bayan Obo show similarities in ore body shape such as 1 . irregular breccia, mineralization style 2. dominant minerals like Magnetite, hematite and copper sulphides and 3. enriched in copper, gold, iron ore, and REE enrichments. 4. The alteration zonation is ranging from sodic to calcic and potassic corroborated in drill core samples with Gadarwara.

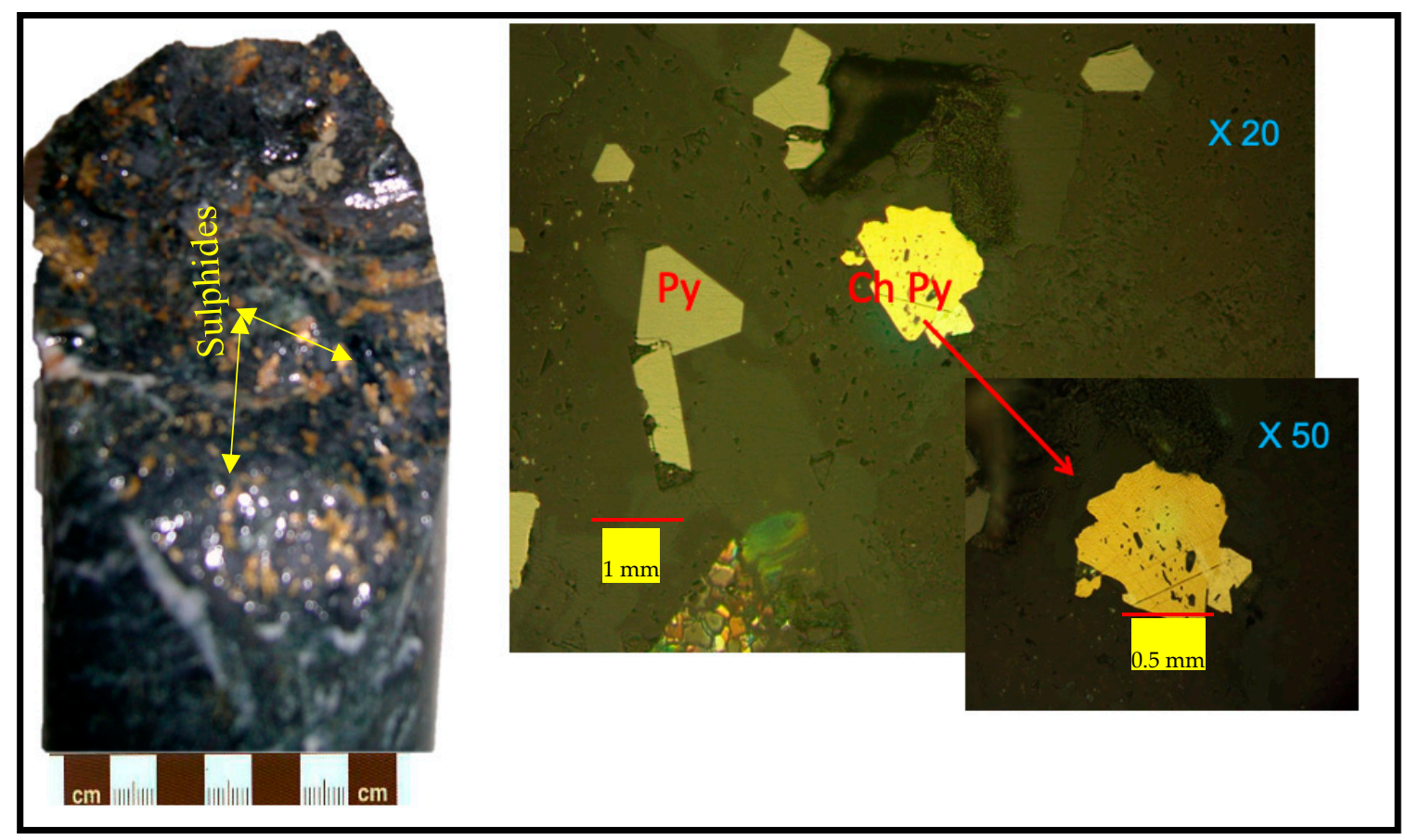

Figure 9. The drill core with sulphides, and petrography reveals Pyrite (Py) and Chalcopyrite (Chpy). 


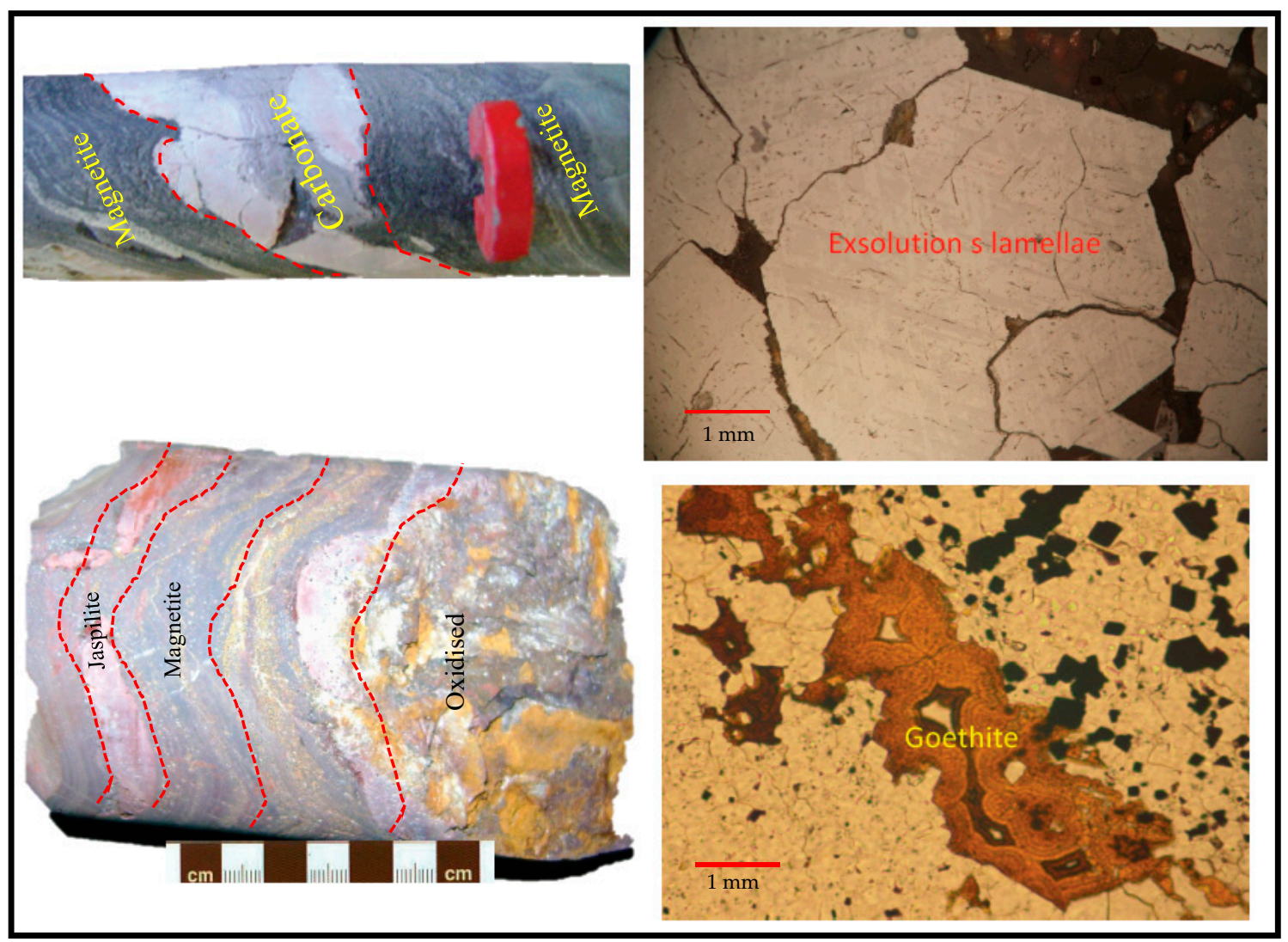

Figure 10. Oxidized brecciated iron formation with goethite and martite.

Table 3. Comparison of similarities of Gadarwara with other IOCG deposits.

\begin{tabular}{|c|c|c|c|c|c|}
\hline Giant Ore Deposit & Type & Mineralisation & Alteration & Commodity & Orebody \\
\hline Olympic Dam, Australia & Olympic Dam & Magnetite-hematite-bornite-chalcopyrite-breccia Matrix & Potassic & $\mathrm{Fe}, \mathrm{Cu}, \mathrm{Au}, \mathrm{Ag}, \mathrm{REE}, \mathrm{U}$ & $\begin{array}{l}\text { Pipe like and } \\
\text { irregular breccia }\end{array}$ \\
\hline $\begin{array}{c}\text { Osborne, } \\
\text { Queensland, Australia }\end{array}$ & Cloncurry & $\begin{array}{l}\text { Magnetite-hematite-apatite replaced by } \mathrm{Cu}-\mathrm{Fe} \\
\text { sulphides, Au etc. }\end{array}$ & Potassic & $\mathrm{Cu}, \mathrm{Au}, \mathrm{Ag}, \mathrm{Bi}, \mathrm{Co}, \mathrm{W}$ & Stratabound vein, breccia \\
\hline Kiirunavaara, Sweden & Kiruna & Massive Magnetite-apatite-actinolite & sodic & $\mathrm{Fe} \pm \mathrm{Cu}, \mathrm{Au}$ & Tabular, pipe like, irregular \\
\hline Magnitogorsk, Urals, Russia & Iron skarn & Massive Magnetite-garnet-pyroxene & Sodic & $\mathrm{Fe} \pm \mathrm{Cu}, \mathrm{Au}$ & $\begin{array}{c}\text { Stratabound } \\
\text { lensoid, irregular }\end{array}$ \\
\hline Phalaborwa, South Africa & Phalaborwa & Magnetite, apatite, fluorite.Cu sulphides & $\begin{array}{l}\text { Sodic }+ \\
\text { potassic }\end{array}$ & $\begin{array}{c}\mathrm{Cu}, \mathrm{Au}, \mathrm{Ag}, \mathrm{REE}, \mathrm{PGE}, \\
\text { vermiculte, Magnetite, } \mathrm{P}, \\
\mathrm{U}, \mathrm{Zr}, \mathrm{Se}, \mathrm{Te}, \mathrm{Bi}\end{array}$ & $\begin{array}{l}\text { Veins, layers, } \\
\text { disseminations }\end{array}$ \\
\hline Bayan Obo, Mongolia, China & Bayan Obo & $\begin{array}{l}\text { Magnetite, hematite, bastnaesite, Fe-Ti-Cr-Nb } \\
\text { oxides, monazite }\end{array}$ & $\begin{array}{l}\text { Weathering of } \\
\text { Fe oxides }\end{array}$ & REE & disseminations \\
\hline $\begin{array}{l}\text { Madhya Pradesh, } \\
\text { Central India }\end{array}$ & Gadarwara & $\begin{array}{l}\text { Magnetite, hematite, } \mathrm{Cu}-\mathrm{Fe}, \mathrm{Au} \text {, monazite, apatite, } \\
\text { zircon, sulphides }\end{array}$ & $\begin{array}{l}\text { Sodic }+ \\
\text { potassic }\end{array}$ & $\mathrm{Cu}, \mathrm{Ni}, \mathrm{Au}, \mathrm{REE}$ & Irregular breccia \\
\hline Western Bastar Craton, India & Thaneswasna & $\begin{array}{l}\text { Magnetite, hematite, pyrite, arsenopyrite, } \\
\text { chalcopyrite, monazite }\end{array}$ & Potassic & Fe-Cu-Ba-Au-Ag-Th & breccia \\
\hline
\end{tabular}

The interpretation of airborne and ground Magnetic profiles using a full dike model provided the initial clues with respect to depth, width, dip, and susceptibility of the causative source as $200 \mathrm{~m}$, $4000 \mathrm{~m}, 42^{\circ} \mathrm{N}$, and $0.004 \mathrm{CGS}$, respectively, in the Gadarwara region [2]. In the initial stages of exploration this paved a way for further detailed ground survey and drilling data were corroborated with the 2D Magnetic modelling studies. The drill hole DDH-1 assay log (Figure 11) distinctly show enrichment of $\mathrm{Cu}, \mathrm{Au}, \mathrm{Cr}, \mathrm{U}$ and $\sum$ REE's (total REE's) and corroborated with global model (Figure 12) as Gadarwara type (GT). 


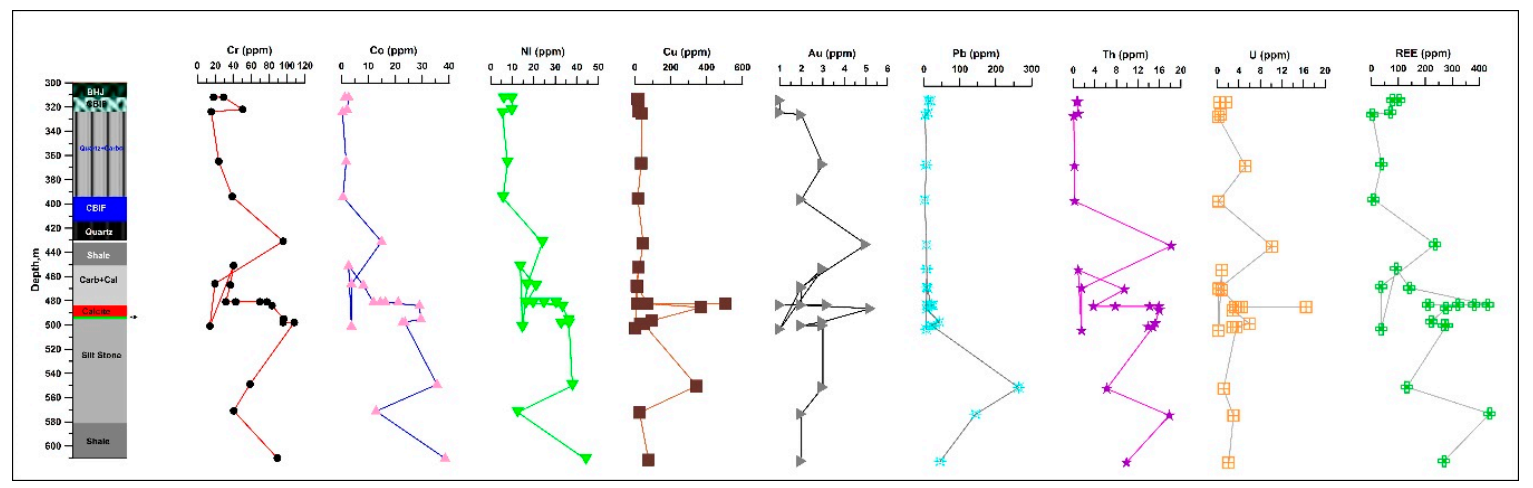

Figure 11. Lithology of DDH-1 drill core with vs assay data.

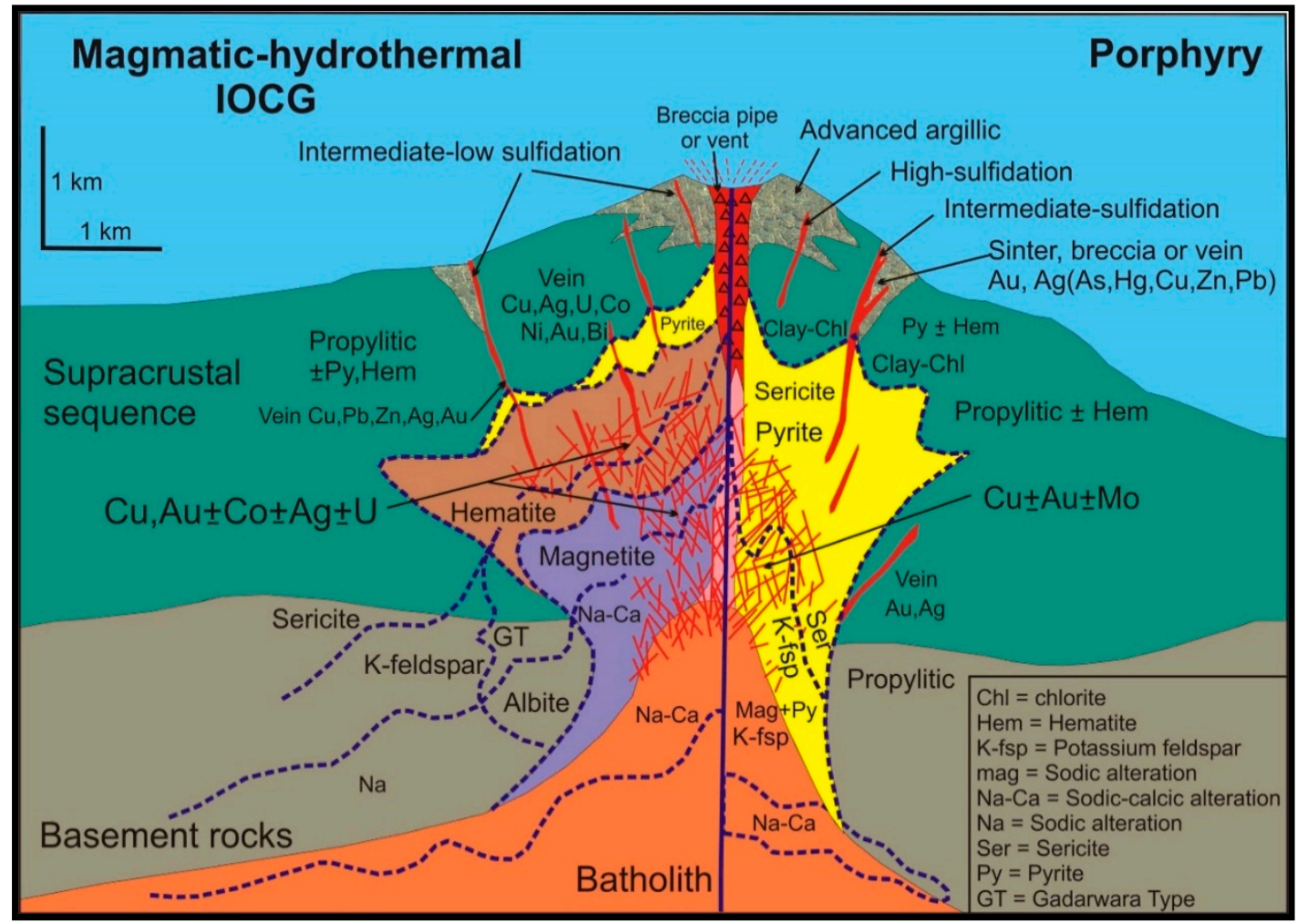

Figure 12. Modified Schematic model for Magmatic-hydrothermal systems illustrating relationship between S-rich porphyry $\mathrm{Cu} \pm \mathrm{Mo} \pm \mathrm{Au}$ deposits (right side) and S-poor Magmatic-hydrothermal iron oxide-copper-gold (MH-IOCG) deposits (left side). Approximate hydrothermal mineral transitions and relative spatial footprint are shown for albite-K-feldspar, K-feldspar-sericite, and magnetite-hematite transitions. Prograde and retrograde overprinting of alteration assemblages and mineralization is common. Spatial relationships for porphyry deposits after Seedorff et al. (2005) [50], Sillitoe (2010) [51], and Richards (2011) [52]; for MH-IOCG, after Hitzman et al. (1992) [48], Williams et al. (2005) [49], and Mumin et al. (2010) [53]. (Figure modified under "Fair- Use" permission from GSA) source: Magmatic-hydrothermal processes within an evolving Earth: Iron oxide-copper-gold and porphyry $\mathrm{Cu} \pm \mathrm{Mo} \pm \mathrm{Au}$ deposits Geology [54].

\section{Conclusions}

Combining our interpretations and drill core observation, we demonstrated the presence of favourable IOCG with Au-Cu mineralization, which are spatially correlated with the redox boundary. The anomaly has been confirmed by integrating the geophysical and geochemical investigations. The 2D Magnetic model suggests a depth of $396 \mathrm{~m}$ with a width of $3.5 \mathrm{~km}$, with a north dipping body 
and southwards bipolar anomaly also suggesting a fault. Structural control like a fault also suggest a significant scope for further investigations. The main key variables giving rise to Gadarwara IOCG are the local host rock types which are diverse in nature. Variation in depth in different structural settings such as breccia at shallow levels and shear hosted at deeper levels. The alteration such as hematite at shallower levels and Magnetite at deeper levels identified at $396 \mathrm{mts}$ in drill hole. Basinal fluids preserved in evaporate-bearing sedimentary successions are important and significant contribution to fluid budget of hematite-rich IOCG system. The mineral footprints in the core samples investigated from Gadarwara suggest that samples have undergone hydrothermal, and oxidation alterations of primary mineralisation. The Potential indicator minerals comprise sheet silicates (i.e., kaolinite, montmorillonite, dickite, mica, chlorite), iron oxides, quartz and carbonates. The PT-variations May have caused a regional transformation of kaolin group minerals and smectites to mica and chlorite. The hydrothermal footprint is expressed by intense silicification related to pervasive quartz veinlets. The oxidation of primary sulphides and iron oxides, such as hematite, Magnetite, iron carbonates (e.g., ankerite, siderite etc.) is typical of but not exclusive to IOCG type of mineralisation. The BIFS are highly oxidised with intense brecciation with hydrothermal overprinting. The EPMA analyses reflect abundant low Ti-Fe oxides, Magnetite, hematite with grunerite and Fe-bearing actinolite. There is also $\mathrm{Na}-\mathrm{K}$ intense metasomatism and Gadarwara is present in a rift type of tectonic environment

Author Contributions: Data curation, P.V.S.R.; formal analysis, K.S.K.; methodology, P.V.S.R. and K.S.K.; project administration, P.V.S.R. and K.S.K.; resources, P.V.S.R; writing一original draft, P.V.S.R.; writing一review and editing, P.V.S.R. and K.S.K. All authors have read and agreed to the published version of the manuscript.

Funding: The research has no external funding

Acknowledgments: P.V.S.R. thank C. Hart for hosting him as a visiting scientist, at MDRU, UBC, Canada. We thank Andrew Nevin, CMD of Adi Gold Mining Pvt Ltd., and M. K. Sen for his support during the study, CSIR, New Delhi, for providing RRF and V.M. Tiwari, Director, CSIR-NGRI for his support. Benjamin, CSIR-TWAS fellow and Hari for preparing figures. We thank three anonymous reviewers for their excellent reviewing which helped to improvise the quality of Manuscript. P.G. Eriksson for his comments and valuable discussions during Manuscript preparation. R.K.W. Merkle for his comments and thoughtful debate on initial MS.

Conflicts of Interest: The authors declare no conflict of interest.

\section{References}

1. Hitzman, M.W.; Porter, T.M. Iron oxide-Cu-Au deposits: What, where, when, and why. Hydrothermal Iron Oxide Copp. -Gold Relat. Depos. A Glob. Perspect. 2000, 1, 9-25.

2. Hitzman, M.W.; Porter, T.M. Current Understanding of Iron Oxide Associated-Alkali Altered Mineralised Systems: Part II, A Review. In 2010 Hydrothermal Iron Oxide Copper-Gold and Related Deposits: A Global Perspective; Porter, T.M., Ed.; PGC Publishing: Adelaide, Australia, 2010; Volume 3, pp. 33-106.

3. Bastrakov, E.N.; Skirrow, R.G. Fluid evolution and origin of $\mathrm{Cu}$ and $\mathrm{Au}$ prospect in the Olympic dam district, Gawler Craton, South Australia. Econ. Geol. 2007, 102, 1415-1440. [CrossRef]

4. Skirrow, R.G.; Bastrakov, E.N.; Barovich, K.; Fraser, G.L.; Creaser, R.A.; Fanning, C.M.; Davidson, G.J. Timing of iron oxide $\mathrm{Cu}-\mathrm{Au}-(\mathrm{U})$ hydrothermal activity and $\mathrm{Nd}$ isotope constraints on metal sources in the Gawler craton, South Australia. Econ. Geol. 2007, 102, 1441-1470. [CrossRef]

5. Ehrig, K.; McPhie, J.; Kamenetsky, V.S. Geology and Mineralogical Zonation of the Olympic Dam Iron-OxideCu-U-Au-Ag Deposit, South Australia. Available online: https://www.researchgate.net/profile/ Vadim_Kamenetsky/publication/291217932_Geology_and_mineralogical_zonation_of_the_Olympic_ Dam_iron_oxide_Cu-U-AuAg_deposit_South_Australia/links/5c403ec1a6fdccd6b5b2dd26/Geology-andmineralogical-zonation-of-the-Olympic-Dam-iron-oxide-Cu-U-Au-Ag-deposit-South-Australia.pdf (accessed on 6 July 2020).

6. Groves, D.I.; Bierlein, F.P.; Meinert, L.D.; Hitzman, M.W. Iron oxide copper-gold (IOCG) deposits through Earth history: Implications for origin, lithospheric setting, and distinction from other epigenetic iron oxide deposits. Econ. Geol. 2010, 105, 641-654. [CrossRef] 
7. Skirrow, R.G. Gold-copper-bismuth deposits of the Tennant Creek district, Australia: A reappraisal of diverse high-grade systems. In Hydrothermal Iron Oxide Copper-Gold E Related Deposits: A Global Perspective; Porter, T.M., Ed.; PGC Publishing: Adelaide, Australia, 2000; Volume 1, pp. 149-160.

8. Williams, P.J.; Corriveau, L.; Mumin, A.H. Magnetite-group IOCGs with special reference to Cloncurry (NW Queensland) and northern Sweden: Settings, alteration, deposit characteristics, fluid sources, and their relationship to apatite-rich iron ores. Geol. Assoc. Can. Short Course Notes 2010, 20, 23-38.

9. Corriveau, L.; Montreuil, J.-F.; Potter, E.G. Alteration facies linkages among IOCG, IOA, and affiliated deposits in the Great Bear Magmatic zone. Can. Econ Geol. 2016, 111, 2045-2072. [CrossRef]

10. Torresi, I.; Xavier, R.P.; Bortholoto, D.F.; Monteiro, L.V. Hydrothermal alteration, fluid inclusions and stable isotope systematics of the Alvo 118 iron oxide-copper-gold deposit, Carajás Mineral Province (Brazil): implications for ore genesis. Miner. Depos. 2012, 47, 299-323. [CrossRef]

11. Hunt, J.A.; Baker, T.; Thorkelson, D.J. A review of iron oxide copper-gold deposits, with focus on the Wernecke Breccias, Yukon, Canada, as an example of a non-magmatic end member and implications for IOCG genesis and classification. Explor. Min. Geol. 2007, 16, 209-232. [CrossRef]

12. Mumin, A.H. The IOCG-Porphyry-Epithermal Continuum of Deposit Types in the Great Bear Magmatic Zone, Northwest Territories, Canada. In Exploring for iron Oxide Copper-Gold Deposits: Canada and Global Analogues; Corriveau, L., Mumin, H., Eds.; Geological Association of Canada: St. John's, NL, Canada, 2010; pp. 59-78.

13. Knight, J. The Khetri copper belt, Rajasthan: iron-oxide copper-gold terrane in the Proterozoic of NW India. In Hydrothermal Iron Oxide Copper-Gold \& Related Deposits: A Global Perspective; Porter, T.M., Ed.; PGC Publishing: Adelaide, Australia, 2002; Volume 2, pp. 321-341.

14. Pal, D.C.; Barton, M.D.; Sarangi, A.K. Deciphering a multistage history affecting U-Cu (-Fe) mineralization in the Singhbhum Shear Zone, eastern India, using pyrite textures and compositions in the Turamdih U-Cu (-Fe) deposit. Miner. Depos. 2009, 44, 61-80. [CrossRef]

15. Corriveau, L.; Potter, E.G.; Montreuil, J.F.; Blein, E.K.; Fabris, A.; Reid, A.J. Alteration facies of IOA, IOCG and affiliated deposit: Understanding the similarities recognising the diversity of the ore systems GSA. In Proceedings of the GSSA Workshop, Qubéc, QC, Canada, 11-12 May 2019.

16. Corriveau, L.; Williams, P.J.; Mumin, A.H. Alteration vectors to IOCG mineralisation-From uncharted terranes to deposits. Can. Glob. Analog. 2010, 20, 89110.

17. Kirmani, I.R.; Chander, S. Petrology, geochemistry and fluid inclusion studies of Cu-Au mineralization in paleoproterozoic Salumber-Ghatol belt, Aravalli Supergroup, Rajasthan. J. Geol. Soc. India. 2012, 80, 5-38.

18. Dora, M.L.; Saha, A.K.; Randive, K.R.; Rao, K.K. Iron oxide-copper-gold mineralization at Thanewasna, western Bastar Craton. Curr.Sci. 2017, 112, 1045-1050. [CrossRef]

19. Shukla, A.K.; Behera, P.; Basavaraja, K.; Mohanty, M. Iron oxide-copper-gold-type mineralization in Machanur area, Eastern Dharwar Craton, India. Curr. Sci. 2016, 5, 1853-1858. [CrossRef]

20. NGRI. High-Resolution Air Borne Geophysical Surveys for Mineral Exploration-Aeromagnetic Discovery of Gadarwara Gold Prospect; NGRI Report; NGRI: Hyderabad, India, 2007; p. 59.

21. Mazumder, R.; De, S.; Sunder Raju, P.V. Archean-Proterozoic transition: the Indian perspective. Earth Sci. Rev. 2019, 188, 427-440. [CrossRef]

22. Crumansonata. Crumansonata Geoscientific studies of the Son-Narmada-Tapti Lineament Zone. Geol. Surv. India Spec. Publ. 1995, 10, 244.

23. Chakraborty, C.; Bhattacharya, A.A. The Vindhyan Basin: An overview in the light of crustal perspective. Mem. Geol. Soc. India. 1996, 36, 301-312.

24. Yedekar, D.B. The central Indian collision suture. Geol. Surv. India, Spec. Publ. 1990, 28, 1-4.

25. Acharyya, S.K.; Roy, A. Tectonothermal history of the Central Indian Tectonic Zone and reactivation of Major faults/shear zones. J. Geol. Soc. India 2000, 55, 239-256.

26. Chattopadhyay, A.; Khasdeo, L. Structural evolution of Gavilgarh-Tan Shear Zone, central India: A possible case of partitioned transpression during Mesoproterozoic oblique collision within Central Indian Tectonic Zone. Precam. Res. 2011, 186, 70-88. [CrossRef]

27. Raju, P.V.S.; Hart, C.; Kathal, P. Newly recognized IOCG-like mineralization at Gadarwara, m.P, India. Mineral. Mag. 2014, 77, 2026. 
28. Mallet, F.R. On the Vindhyan Series, as exhibited in the north-western and central provinces of India. Mem. Geol. Surv. India. 1869, 7, 1-129.

29. Ghosh, D.B. The nature of Narmada-Son Lineament. Geol. Surv. India Misc. Pub. 1976, 34, 119-132.

30. Nair, K.K.K. Stratigraphy, structure and geochemistry of the Mahakoshal greenstone. Mem. Geol. Soc. India. 1995, 37, 403-432.

31. Babu, H.R. Relationship of gravity, Magnetic, and self-potential anomalies and their application to mineral exploration. Geophysics 2003, 68, 181-184. [CrossRef]

32. Bickford, M.E.; Mishra, M.; Mueller, P.A.; Kamenov, G.D.; Schieber, J.; Basu, A. U-Pb age and Hf isotopic compositions of Magmatic zircons from a rhyolite flow in the Porcellanite Formation in the Vindhyan Supergroup, Son Valley (India): implications for its tectonic significance. J. Geol. 2017, 125, 367-379. [CrossRef]

33. Ray, J.S.; Martin, M.W.; Veizer, J.; Bowring, S.A. U-Pb zircon dating and Sr isotope systematics of the Vindhyan Supergroup, India. Geology 2002, 30, 131-134. [CrossRef]

34. Kumar, S.; Schidlowski, M.; Joachimski, M.M. Carbon isotope stratigraphy of the Palaeo-Neoproterozoic Vindhyan Supergroup, central India: implications for basin evolution and intrabasinal correlation. J. Palaeontol. Soc. India 2005, 50, 65-81.

35. Jain, S.C.; Nair, K.K.K.; Yedekar, D.B. Tectonic evolution of the Son-Narmada-Tapti lineament zone. Geol. Surv. India Spec. Pub. 1995, 10, 333-371.

36. Mishra, D.C. Gravity and Magnetic Methods for Geological Studies; BS Publications: Hyderabad, India, 2011.

37. Rao, D.A.; Babu,H.R.; Sinha, G.S. Crustal structure associated with Gondwana graben across the Narmada-Son lineament in India: inference from aeromagnetics. Tectonophysics 1992, 212, 163-172. [CrossRef]

38. Medlicott, H.B. Notes on Satpura Coal Basin. Mem. Geol. Surv. India 1873, 10, 133-188.

39. Medlicott, H.B.; Blanford, W.T. A Manual Geology of India; Govt of India Press: Calcutta, India, 1879.

40. Talwani, M. Computation of Magnetic anomalies caused by two-dimensional bodies of arbitrary shape. Comput. Miner. Ind. 1964, 1, 464-480.

41. Spector, A.; Bhattacharyya, B.K. Energy density spectrum and autocorrelation function of anomalies due to simple Magnetic models. Geophys. Prospect. 1966, 14, 242-272. [CrossRef]

42. Spector, A.; Grant, F.S. Statistical models for interpreting aeromagnetic data. Geophysics 1970, 35, $293-302$. [CrossRef]

43. MacLeod, I.N.; Jones, K.; Dai, T.F. 3-D analytic signal in the interpretation of total Magnetic field data at low Magnetic latitudes. Explor. Geophys. 1993, 24, 679-688. [CrossRef]

44. PGW. Program Documentation-MAGMOD Version 1.4 Magnetic Interpretation Software Library; Paterson, Grant and Watson Ltd.: Toronto, ON, Canada, 1982; p. 17.

45. Raju, P.V.S.; Hart, C.; Kathal, P. Integrated SWIR spectral and XRD studies on core samples from Gadarwara, Central India Craton, Madhya Pradesh, India-footprints for IOCG mineralisation. In Proceedings of the 14th SGA Biennial Meeting, Québec, QC, Canada, 20-23 August 2017; pp. 963-966.

46. Haynes, D.W.; Porter, T.M. Iron oxide copper (-gold) deposits: Their position in the ore deposit spectrum and modes of origin. Hydrothermal Iron Oxide Copp. -Gold Relat. Depos. A Glob. Perspect. 2000, 1, 71-90.

47. Hitzman, M.W.; Oreskes, N.; Einaudi, M.T. Geological characteristics and tectonic setting of proterozoic iron oxide (Cu-U-Au-REE) deposits. Precambrian Res. 1992, 58, 241-287. [CrossRef]

48. Belperio, A.; Flint, R.; Freeman, H. Prominent hill: a hematite-dominated iron oxide copper gold system. Econ. Geol. 2007, 102, 1499-1510. [CrossRef]

49. Williams, P.J.; Barton, M.D.; Johnson, D.A.; Fontboté, L.; De Haller, A.; Mark, G.; Marschik, R. Iron oxide copper-gold deposits: Geology, space-time distribution, and possible modes of origin. Econ. Geol. 2005, 100, 371-405. [CrossRef]

50. Seedorff, E.; Dilles, J.H.; Proffett, J.M., Jr.; Einaudi, M.T.; Zurcher, L.; Stavast, W.J.A.; Johnson, D.A.; Barton, M.D. Porphyry Deposits: Characteristics and Origin of Hypogene Features. Econ. Geol. 2005, 100, 251-298.

51. Sillitoe, R.H. Porphyry copper systems. Econ. Geol. 2010, 105, 3-41. [CrossRef]

52. Richards, J.P. Magmatic to hydrothermal metal fluxes in convergent and collided Margins. Ore Geol Rev. 2011, 40, 1-26. [CrossRef] 
53. Mumin, A.H.; Phillips, A.; Katsuragi, C.J.; Mumin, A.; Ivanov, G. Geotectonic Interpretation of the Echo Bay Sratovolcano Complex, Northern Great Bear Magmatic Zone; Northwest Territories Geoscience Office: Yellowknife, NT, Canada, 2013; p. 35.

54. Richards, J.P.; Mumin, A.H. Magmatic-hydrothermal processes within an evolving Earth: Iron oxide-copper-gold and porphyry $\mathrm{Cu} \pm \mathrm{Mo} \pm \mathrm{Au}$ deposits. Geology 2013, 41, 767-770. [CrossRef] 